\title{
A RARE CASE OF OVARIAN TUMOUR IN AN ADOLESCENT GIRL
}

\author{
Muthuramu Poovathi' ${ }^{1}$ Al Santhi ${ }^{2}$
}

${ }_{1}^{1}$ Professor, Department of Obstetrics and Gynaecology, Thanjavur Medical College, Thanjavur. 2Professor, Department of Pathology, Thanjavur Medical College, Thanjavur.

\section{ABSTRACT}

Stromal cell tumour of the ovary is a rare benign tumour occurring predominantly in $2^{\text {nd }}$ and $3^{\text {rd }}$ decade of life is extremely rare tumour with distinctive pathological features and benign in nature. ${ }^{1}$ Usually occurs in younger age group and predominantly of 14 and 29 years of age. ${ }^{2}$ This 16-year-old girl came to Outpatient Department in a Tertiary Care Hospital, Raja Mirasdhar Hospital, Thanjavur, with complaints of massive distention of abdomen with one-month duration and with menstrual disturbance. There were no other features of virilization and biochemical evidence of hyperandrogenism. It is unilateral in our case, but bilateral occurrences also have been reported.

\section{KEYWORDS}

Sclerosing Tumour, Ovarian Tumour, Menorrhagia.

HOW TO CITE THIS ARTICLE: Poovathi M, Santhi AL. A rare case of ovarian tumour in an adolescent girl. J. Evolution Med. Dent. Sci. 2016;5(12):523-525, DOI: 10.14260/jemds/2016/120

\section{INTRODUCTION}

A 16-year-old girl admitted with complaints of lower abdominal pain and distension for 1 month. Excess bleeding per vaginum on and off for 1 month associated with changing 3-5 pads/day not associated with passage of clots. Clinically, there were no signs and symptoms of malignancy, hyperestrogenism and hyperandrogenism.

\section{Per Abdomen Examination Shows}

Tense cystic mass of size $20 \times 15 \mathrm{~cm}$ arising from pelvis occupying both iliac fossa, extends up to umbilicus, regular margins, not tender, restricted mobility, no dilated/engorged veins, no other mass palpable, no organomegaly. $\mathrm{Hb}-9 \mathrm{~g}$, CBCwithin normal limits RBS, RFT, LFT- within normal limits. Tumor markers- CA-125 -36U/ml, AFP - $1.07 \mathrm{ng} / \mathrm{ml}$.

USG findings were right ovarian cyst $15 \times 11 \mathrm{~cm}$, left ovarian cyst $2.6 \times 2.4 \mathrm{~cm}$. Uterus normal ET $5 \mathrm{~mm}$, right hydroureteronephrosis. No focal lesion noted in liver. Mild ascites present. Usually, these tumors tend to present as cystic masses.

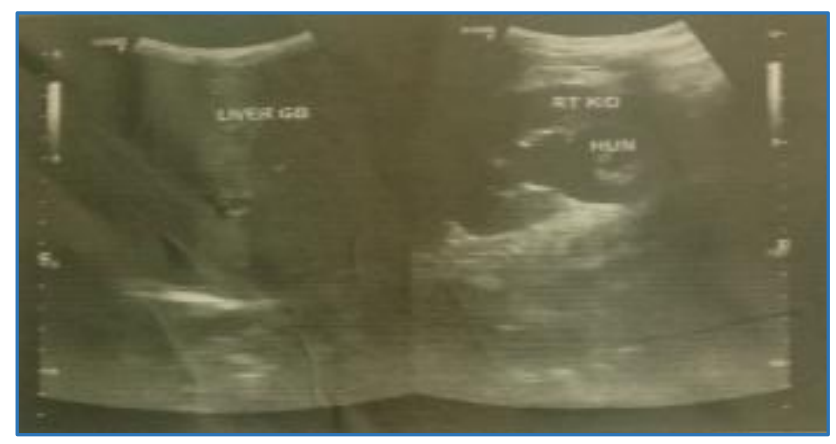

Financial or Other, Competing Interest: None.

Submission 24-12-2015, Peer Review 23-01-2016,

Acceptance 28-01-2016, Published 11-02-2016.

Corresponding Author:

Muthuramu Poovathi,

1672/124, Ragavendra Nagar,

No. 1, Toll Gate, Trichy-621216.

E-mail:drmpoovathi@gmail.com

DOI:10.14260/jemds/2016/120
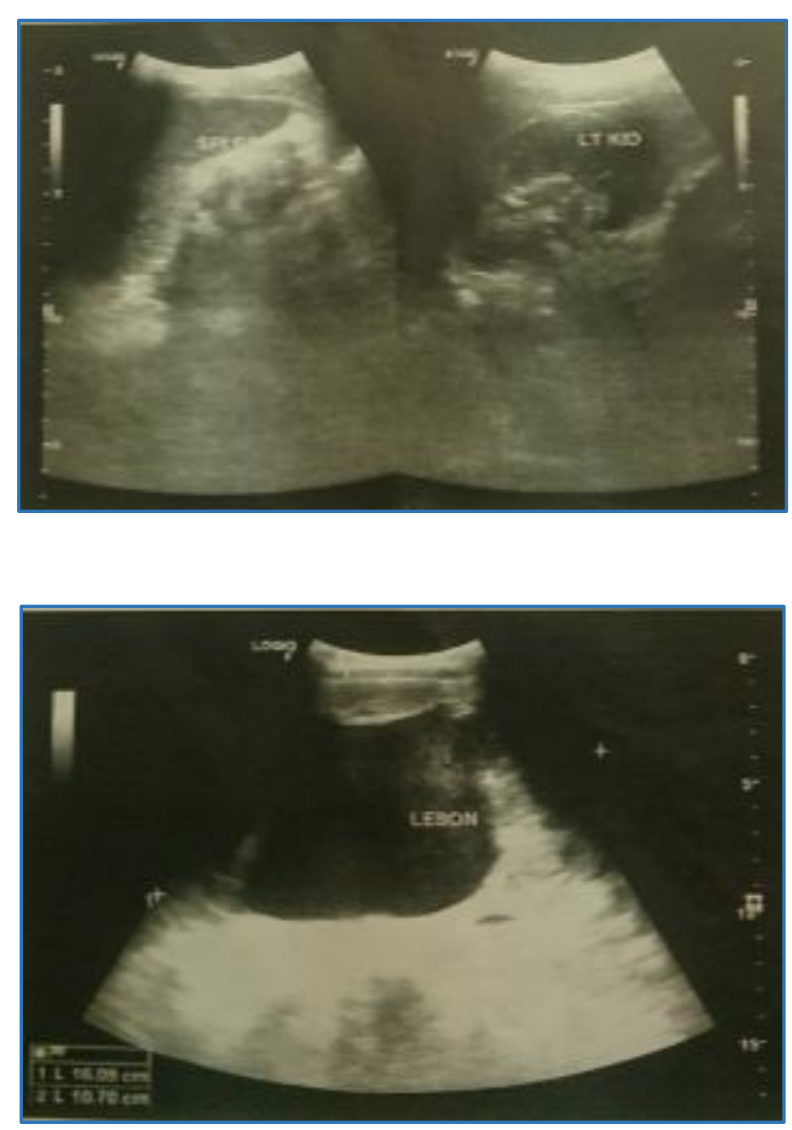

Fig. 1: USG showing large cystic lesion in right ovary CT Abdomen Shows

Right ovarian cyst of size $17 \times 10 \mathrm{~cm}$ with thick capsule. Left ovarian cyst of size $2.5 \times 2.4 \mathrm{~cm}$. Uterus normal, right hydroureteronephrosis, mild ascites. No enlargement of nodes. Other viscera normal. 


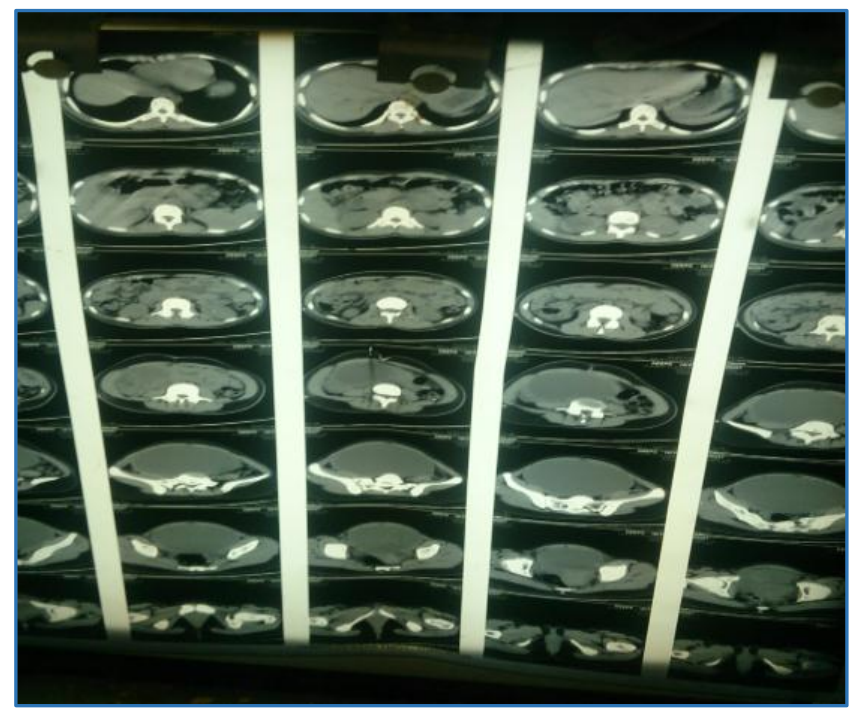

Fig. 2: Computed tomography of abdomen and pelvis reveals right ovarian mass of $17 \times 10 \mathrm{~cm}$

Planned for staging laparotomy.

\section{Intraoperative Findings}

A $50 \mathrm{ml}$ of straw coloured ascitic fluid aspirated and sent for cytology. Uterus-normal size.

Large tumor of size $20 \times 18 \mathrm{~cm}$ arising from right ovary with torsion of its pedicle. Right tube stretched over ovarian tumor. Left ovary cyst of size $2.5 \times 2.4 \mathrm{~cm}$. Right salpingoophorectomy done and omental biopsy taken.

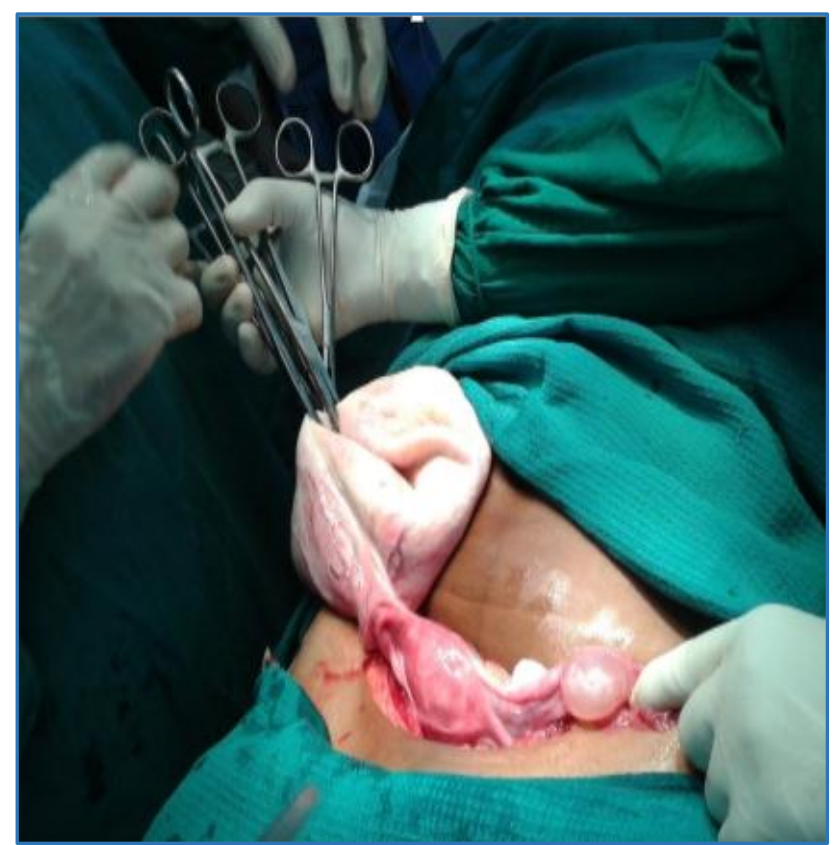

Fig. 3: Showing Large Right Ovarian Cyst, Normal Uterus and Small Left Ovarian Cyst

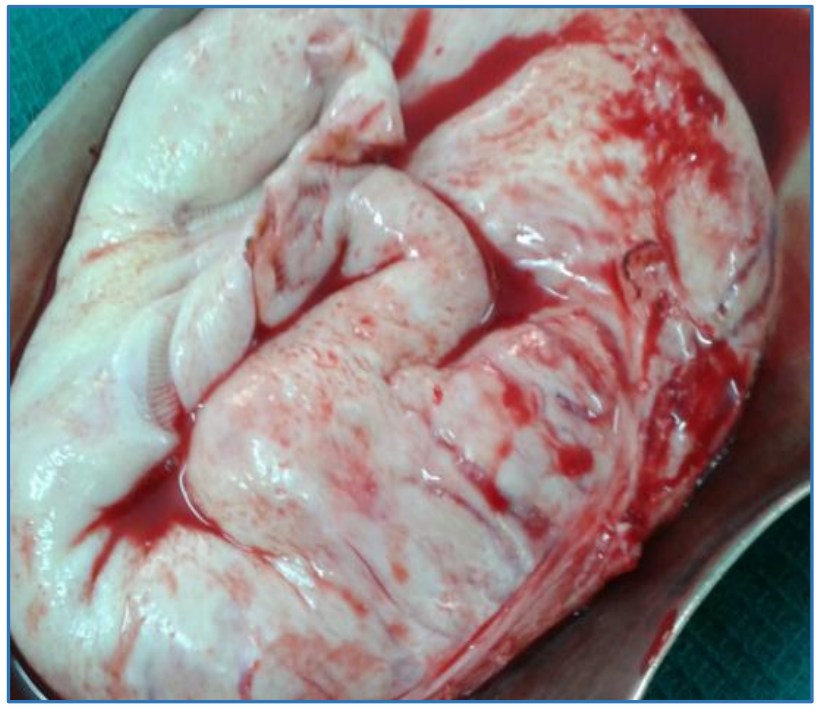

Fig. 4: Large cyst after emptying the clear fluid in the cyst

Uniloculated, thick capsule, no capsular breach, no solid components.

\section{Postoperative Period}

Uneventful, patient discharged on $6^{\text {th }}$ postoperative day.

- $\quad$ Ascitic fluid analysis- No evidence of malignant cells Omental biopsy shows- Few lymphocytes, occasional mesothelial cells, no malignant cells.

HPE report- Sclerosing Stromal Cell Ovarian Tumour

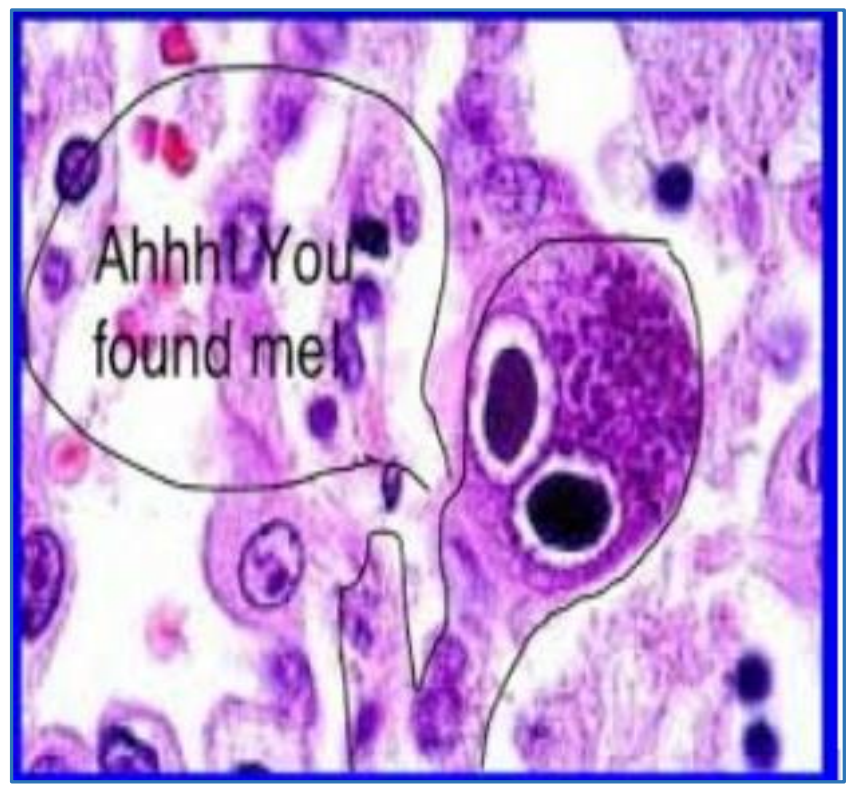

Fig. 5: HPE showing sclerosing cells 


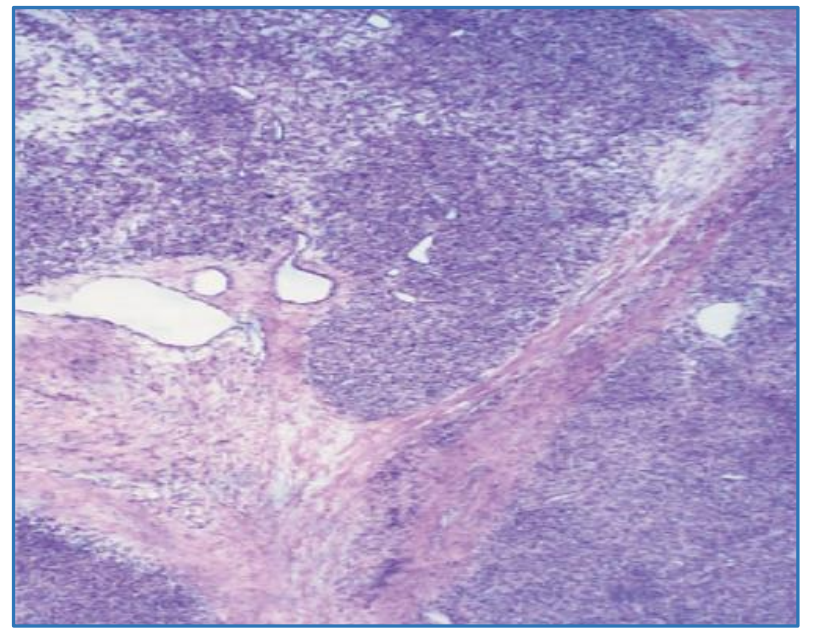

Fig. 6: HPE picture of sclerosing stromal cell tumour of ovary

\section{DISCUSSION}

Sclerosing stromal tumors are usually hormonally inactive. If hormonally active, they are usually androgenic and occur most frequently during pregnancy. Menstrual irregularity and pelvic pain are the most frequent complaints during presentation. SST is attributable to theca cell fibrous tumour subtypes of ovarian sex cord-stromal tumor from WHO-2003 classification that is distinctive clinical, pathologic and radiological features, which differentiates it from other stromal tumour. ${ }^{3}$ The aetiology is unknown. However, it has been proposed to originate from perifollicular myoid stromal cells that are normally present in the theca externa. ${ }^{4} \mathrm{~A} 2 \%$ to $6 \%$ of ovarian tumors originating from stroma of ovary. First described by Chalvardjian and Scully in 1973; 114 cases have been described in literature. Benign tumor, but one case of tumor with low-grade potential have been described. Presents predominantly in the second and third decades of life.

- Immunohistochemical markers. Positive for vimentin, actin and inhibin. Negative for CD-199 and S100. ${ }^{5}$

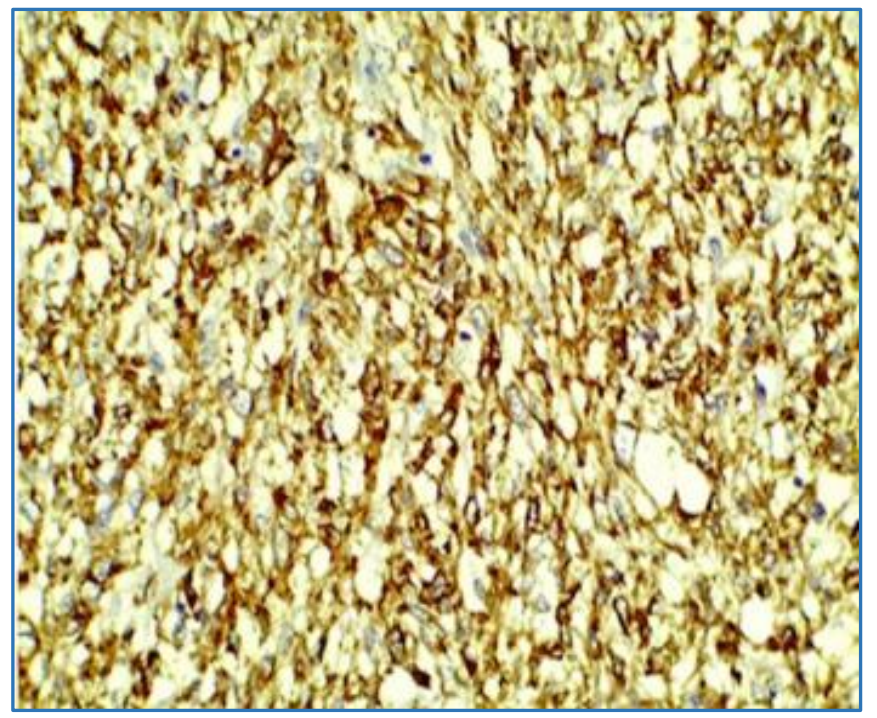

Fig. 7: Actin Positive

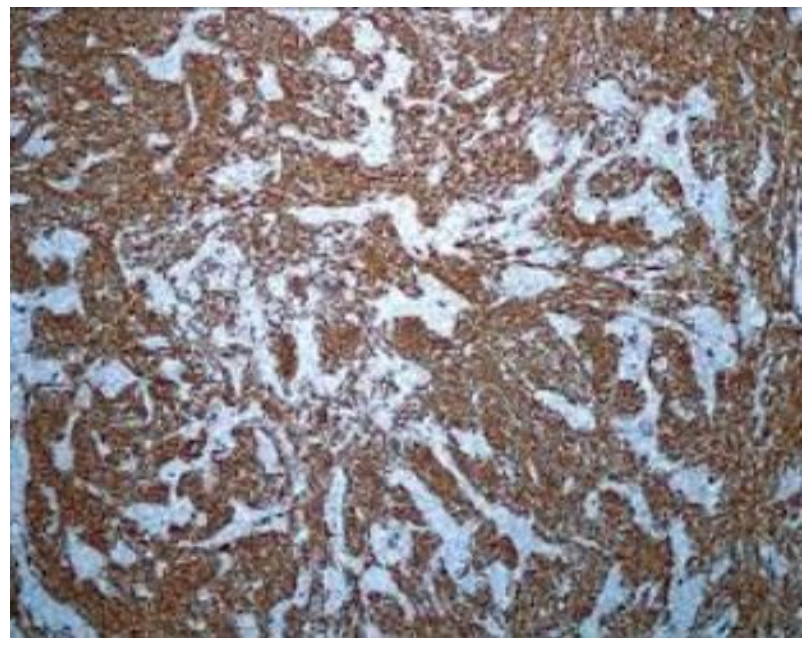

Fig. 8: Inhibin Positive

\section{CONCLUSION}

Due to the rarity of this neoplasm, it is not always possible to predict the presence of this tumor preoperatively on the basis of clinical and radiological findings.

The possibility of sclerosing stromal tumor should always be kept in young patients with ovarian mass, as these are benign and can be treated successfully by enucleation or unilateral ovariotomy.

\section{REFERENCES}

1. Chalvardjian A, Scully RE. Sclerosing stromal tumor of the ovary. PubMed 1973;31:664-70.

2. Kim JY, Jung KJ, Chung DS, et al. Sclerosing stromal tumor of the ovary. MR-pathologic correlation in three cases. Korean J Radiol 2003;4:194-9.

3. Liang YF, Zeng JC, Ruan JB, et al. Ovarian sclerosing stromal tumor in a young woman with ectopic pregnancy: clinical, pathological and immunohistological studies. Int J Clin Exp Pathol 2013;7:456-9.

4. Kaygusuz EI, Cesur S, Cetiner H, et al. Sclerosing stromal tumor in young women: clinicopathologic and immunehistochemical spectrum. J Clin Diagn Res 2013; 7:19321935.

5. Zekioglu O, Ozdemir N, Terek C, et al. Clinicopathological and immunohistochemical analysis of sclerosing stromal tumor of the ovary. Arch Gynecol Obstet 2010; 282(6): 671-6. 